\title{
Intermetallic Reactions in a Sn-20In-2.8Ag Solder Ball-Grid-Array Package with Au/Ni/Cu Pads
}

\author{
HUI-MIN WU, ${ }^{1,2}$ FENG-CHIH WU, ${ }^{1}$ and TUNG-HAN CHUANG ${ }^{1}$ \\ 1.--Institute of Materials Science and Engineering, National Taiwan University, Taipei 106, \\ Taiwan. 2.—E-mail: D92527008@ntu.edu.tw
}

The intermetallic compounds formed during the reflow and aging of Sn-20In$2.8 \mathrm{Ag}$ ball-grid-array (BGA) packages are investigated. After reflow, a large number of cubic-shaped $\mathrm{AuIn}_{2}$ intermetallics accompanied by $\mathrm{Ag}_{2} \mathrm{In}$ precipitates appear in the solder matrix, while a $\mathrm{Ni}\left(\mathrm{Sn}_{0.72} \mathrm{Ni}_{0.28}\right)_{2}$ intermetallic layer is formed at the solder/pad interface. With further aging at $100^{\circ} \mathrm{C}$, many voids can be observed in the solder matrix and at the solder/pad interface. The continuous distribution of voids at the interface of specimens after prolonged aging at $100^{\circ} \mathrm{C}$ causes their bonding strength to decrease from $5.03 \mathrm{~N}$ (as reflowed) to about $3.50 \mathrm{~N}$. Aging at $150^{\circ} \mathrm{C}$ induces many column-shaped $\left(\mathrm{Cu}_{0.74} \mathrm{Ni}_{0.26}\right)_{6}\left(\mathrm{Sn}_{0.92} \mathrm{In}_{0.08}\right)_{5}$ intermetallic compounds to grow rapidly and expand from the solder/pad interface into the solder matrix. The high microhardness of these intermetallic columns causes the bonding strength of the Sn-20In-2.8Ag BGA solder joints to increase to $5.68 \mathrm{~N}$ after aging at $150^{\circ} \mathrm{C}$ for $500 \mathrm{~h}$.

Key words: Ball-grid-array (BGA), Sn-20In-2.8Ag solder, intermetallic compounds, ball shear strength

\section{INTRODUCTION}

Among a number of candidates, the eutectic alloy Sn-3.5Ag has been considered to be one of the most promising lead-free solders due to its advantages of higher shear strength, improved creep resistance, longer thermal fatigue life, and good wettability. ${ }^{1-3}$ However, this alloy has a higher eutectic point than the traditional $\mathrm{Sn}-37 \mathrm{~Pb}$ solder, which has certainly restricted its applications in electronic packaging. In order to solve this problem, Hiroshi et al. ${ }^{4}$ found that the melting temperature of $\mathrm{Sn}-3.5 \mathrm{Ag}$ solder could fall slightly from $216^{\circ} \mathrm{C}$ to $193^{\circ} \mathrm{C}$ by adding a small amount of $\mathrm{Zn}$. The addition of $\mathrm{Bi}$ into solders has also been found by Kattner and Boettinger ${ }^{5}$ to lower its liquidus temperature. Kariya and Ostuka further reported that $\mathrm{Zn}$ and indium (In) additions could improve the tensile strength while the fatigue life would slightly decrease, and a $\mathrm{Bi}$ addition, on the other hand, would degrade the fatigue life of Sn3.5Ag abruptly. ${ }^{6}$

It is well known that In addition has a remarkable effect on lowering the melting temperatures of

(Received May 26, 2005; accepted June 27, 2005) solders. Glarzer showed that $\mathrm{Au}$ atoms dissolved quite slowly into the In-containing solder. ${ }^{7}$ Lee also reported that the lower solubility of $\mathrm{Au}$ atoms in the In-Sn solder resulted in the prevention of Au-embrittlement failure in advanced packaging. ${ }^{8}$ Jacobson and Humpson found that, in an Incontained solder, a AuIn intermetallic layer appeared at the solder/pad interface, which acted as a diffusion barrier and prohibited the formation of brittle intermetallic phase such as $\mathrm{AuSn}_{4}$ in the solder matrix. ${ }^{9}$ Yet, the element In is expensive enough to restrain the applications of In-containing solders in electronic packaging. A compromise may be reached by integrating the features of Sn-3.5Ag and In-49Sn alloys, and having Sn-20In-2.8Ag solder developed. Kim and $\mathrm{Tu}^{10}$ reported that $\mathrm{Sn}-20 \mathrm{In}-2.8 \mathrm{Ag}$ solder exhibited a lower dissolution rate for the $\mathrm{Au}$ element when compared with other $\mathrm{Pb}$ - and Sn-based solders. In our prior studies, the intermetallic compounds formed during the solder reactions of $\mathrm{Sn}-20 \mathrm{In}-2.8 \mathrm{Ag}$ alloy with $\mathrm{Cu}$, $\mathrm{Ni}$, and Ag substrates were analyzed. ${ }^{11-13}$ The effort of this study is concerned with further investigations of the interfacial reactions between $\mathrm{Sn}-20 \mathrm{In}-2.8 \mathrm{Ag}$ solder and $\mathrm{Au} / \mathrm{Ni} / \mathrm{Cu}$ pads in ball-grid-array (BGA) packages during reflow and aging. 


\section{EXPERIMENTAL PROCEDURES}

The BGA packages were assembled in the same manner as a previous study. ${ }^{14}$ The Sn-20In-2.8Ag solder balls were dipped in RMA-type flux, placed on the $\mathrm{Au} / \mathrm{Ni} / \mathrm{Cu}$ pads in BGA packages, and then heated in a hot-air furnace. The DSC analysis showed that the solidus and liquidus temperatures of the Sn-20In-2.8Ag solder alloy were $176^{\circ} \mathrm{C}$ and $187^{\circ} \mathrm{C}$, respectively. For the reflow process, various peak temperatures $\left(\mathrm{T}_{\max }\right)$ ranging from $200^{\circ} \mathrm{C}$ to $230^{\circ} \mathrm{C}$ for various melting time periods $(\Delta \mathrm{t})$ were used. A certain number of BGA specimens reflowed at $230^{\circ} \mathrm{C}$ peak temperature for $60 \mathrm{sec}$ melting time were further aged at $100^{\circ} \mathrm{C}$ and $150^{\circ} \mathrm{C}$, respectively, for the durations varying from $100 \mathrm{~h}$ to $1000 \mathrm{~h}$.

For metallographic observations, the reflowed and aged specimens were cross-sectioned through a row of solder balls, ground with 1500 grit $\mathrm{SiC}$ paper, and polished with $0.3 \mu \mathrm{m} \mathrm{Al}_{2} \mathrm{O}_{3}$. A scanning electron microscope (SEM) equipped with an energy dispersive $\mathrm{x}$-ray spectrometer (EDX) was employed for the examination of the morphology and chemical composition of intermetallic compounds formed in the BGA packages. The three-dimensional morphology of intermetallics was also observed by means of the selective etching method. For this purpose, an etching solution of $35 \mathrm{~mL} \mathrm{HF}, 55 \mathrm{~mL} \mathrm{H}_{2} \mathrm{O}_{2}$, and $10 \mathrm{~mL} \mathrm{HNO}_{3}$ was used to dissolve the unreacted Sn-20In-2.8Ag solder and retain the intermetallic compounds at the solder/pad interfaces.

Finally, the bonding strengths of Sn-20In-2.8Ag solder joints under various reflow and aging conditions were measured via ball shear testing. The measurements were taken at a shear rate of $0.1 \mathrm{~mm} / \mathrm{s}$ and a shear height of $80 \mu \mathrm{m}$ (about $1 / 4$ of the reflowed ball height). The fractography of the solder joints after ball shear tests was observed by SEM.

\section{RESULTS AND DISCUSSION}

The microstructure of the as-cast Sn-20In-2.8Ag alloy is shown in Fig. 1a, which contains island-like $\mathrm{Ag}_{2}$ In precipitates embedded in the Sn-rich matrix. Figure $1 b$ reveals the appearance of a number of cubic-shaped $\mathrm{AuIn}_{2}$ intermetallic compounds in the solder in addition to $\mathrm{Ag}_{2} \mathrm{In}$ precipitates after the reflow of Sn-20In-2.8Ag solder balls on $\mathrm{Au} / \mathrm{Ni} / \mathrm{Cu}$ pads in BGA packages. The formation of such $\mathrm{AuIn}_{2}$ intermetallic cubics has already been reported in In-49Sn solder BGA packages with $\mathrm{Au} / \mathrm{Ni} / \mathrm{Cu}$ pads. ${ }^{14}$ According to Fig. 2, as the peak temperature or melting duration for the reflow process increases, more cubic-shaped intermetallic compounds float into the solder matrix. The three-dimensional morphology of intermetallic compounds at the solder/pad interface after reflow can be observed through selective etching of the Sn-20In-2.8Ag solder. Figure 3 reveals that many $\mathrm{AuIn}_{2}$ intermetallic cubics accompanied by seaweed-shaped $\mathrm{Ag}_{2} \mathrm{In}$ still remain on the $\mathrm{Ni} / \mathrm{Cu}$ pad in the BGA package. Along with the formation of $\mathrm{AuIn}_{2}$ intermetallics, the Au film disappears, while
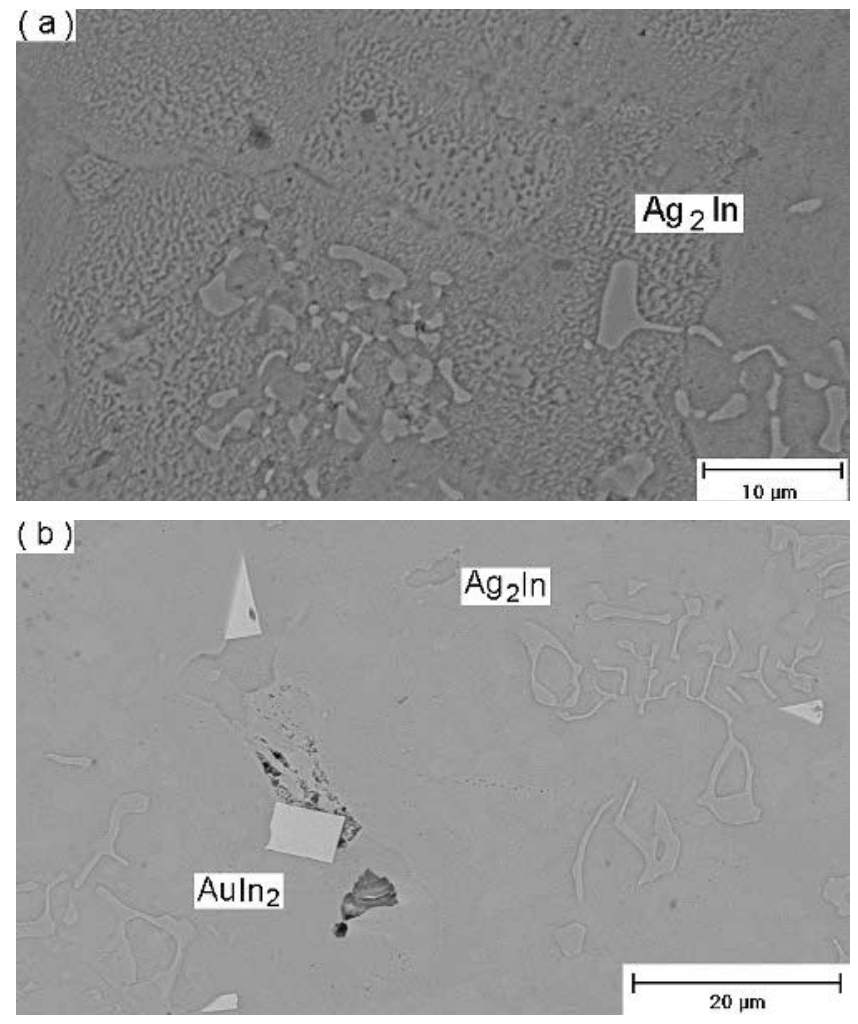

Fig. 1. Microstructure of the Sn-20In-2.8Ag solder matrix: (a) as cast and (b) as reflowed on $\mathrm{Au} / \mathrm{Ni} / \mathrm{Cu}$ pads.

the liquid $\mathrm{Sn}-20 \mathrm{In}-2.8 \mathrm{Ag}$ solder reacts further with the $\mathrm{Ni}$ layer to form a continuous intermetallic layer at the solder/pad interface as shown by Fig. 4 . The composition (at.\%) of this interfacial intermetallic layer as analyzed by EDX is Ni:Sn:In = 33.5:48.5: 18.0, which corresponds to the $\mathrm{Ni}\left(\mathrm{Sn}_{0.72} \mathrm{In}_{0.27}\right)_{2}$ phase. The resultant interfacial intermetallic phase in the Sn-20In-2.8Ag solder BGA package is consistent with the reaction product generated from the In49Sn ${ }_{(\mathrm{L})} / \mathrm{Ni}_{(\mathrm{S})}$ soldering reactions, ${ }^{15}$ rather than with the $\mathrm{Ni}_{3}\left(\mathrm{Sn}_{0.99} \mathrm{In}_{0.01}\right)_{4}$ phase formed in the soldering reaction between liquid $\mathrm{Sn}-20 \mathrm{In}-2.8 \mathrm{Ag}$ solder and $\mathrm{Ni}$ substrate. ${ }^{16}$ Such a $\mathrm{Ni}\left(\mathrm{Sn}_{0.72} \mathrm{In}_{0.28}\right)_{2}$ phase can be inferred to exist in the Ni-Sn-In ternary phase diagram, ${ }^{17}$ although there has been no report of either the $\mathrm{NiSn}_{2}$ or the $\mathrm{NiIn}_{2}$ phase in the Ni-Sn and Ni-In binary phase diagrams.

Figure 5 shows the morphology of intermetallic compounds in Sn-20In-2.8Ag solder BGA packages with $\mathrm{Au} / \mathrm{Ni} / \mathrm{Cu}$ pads after aging at $100^{\circ} \mathrm{C}$ for various time periods. It can be seen that the interfacial intermetallic compounds $\mathrm{Ni}\left(\mathrm{Sn}_{0.72} \mathrm{In}_{0.28}\right)_{2}$ formed during reflow have not grown noticeably with the aging time, but the voids in the solder matrix have increased gradually. With the aging time prolonged to more than $700 \mathrm{~h}$, a row of voids appear at the solder/pad interface as shown in Fig. 5c and d. Figure 6 indicates that the voids are linked to form a crack along the solder/pad interface. However, as the aging temperature is increased from $100^{\circ} \mathrm{C}$ to $150^{\circ} \mathrm{C}$, the $\mathrm{Ni}$ metallization layer becomes 

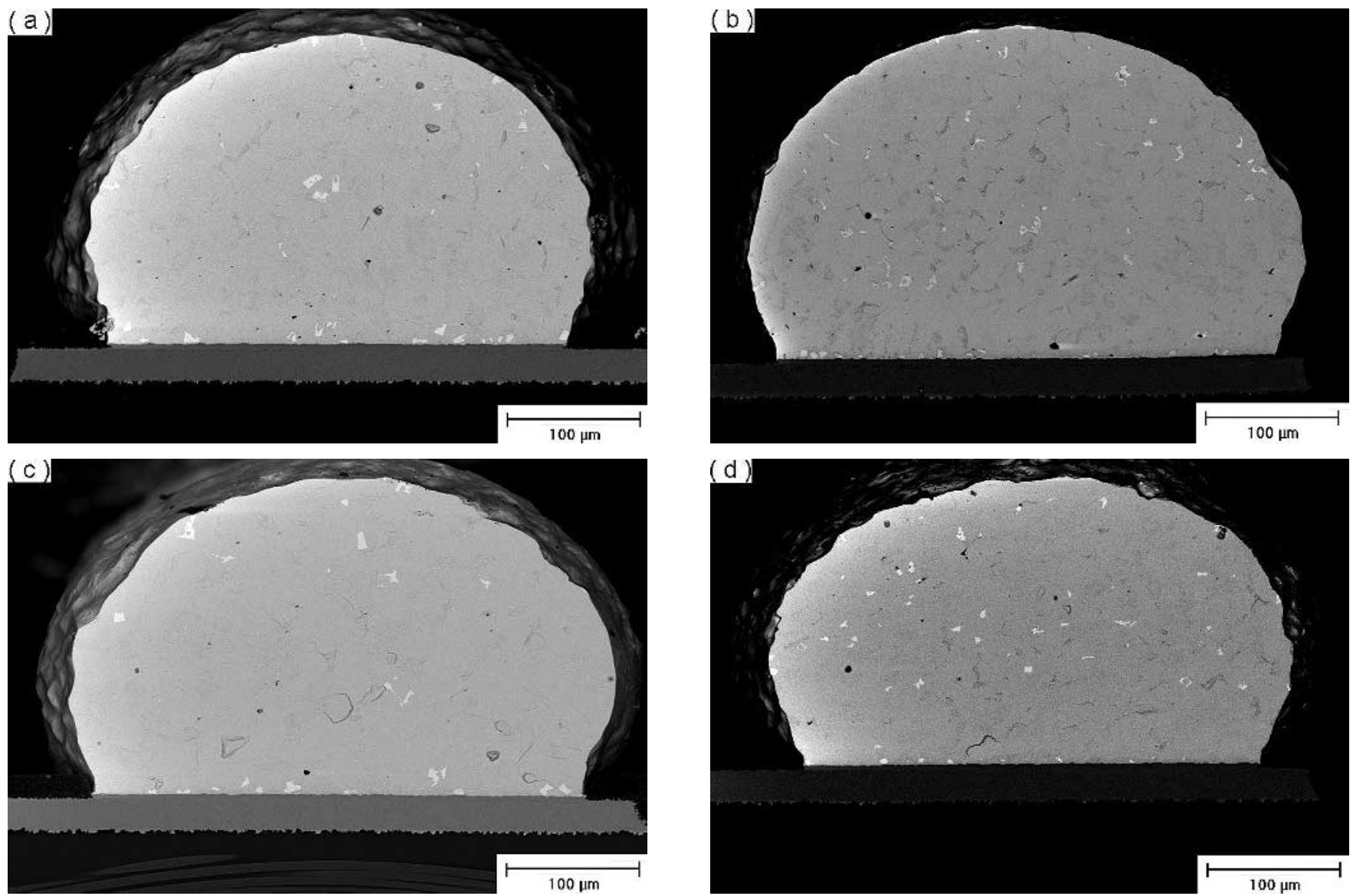

Fig. 2. Morphology of the intermetallic compounds formed in the $\mathrm{Sn}-20 \mathrm{In}-2.8 \mathrm{Ag}$ solder BGA package with $\mathrm{Au} / \mathrm{Ni} / \mathrm{Cu}$ pads after reflowing at various peak temperatures for various melting durations: (a) $200^{\circ} \mathrm{C}, 60 \mathrm{sec}$; (b) $230^{\circ} \mathrm{C}, 60 \mathrm{sec}$; (c) $200^{\circ} \mathrm{C}, 120 \mathrm{sec}$; and (d) $230^{\circ} \mathrm{C}, 120 \mathrm{sec}$.

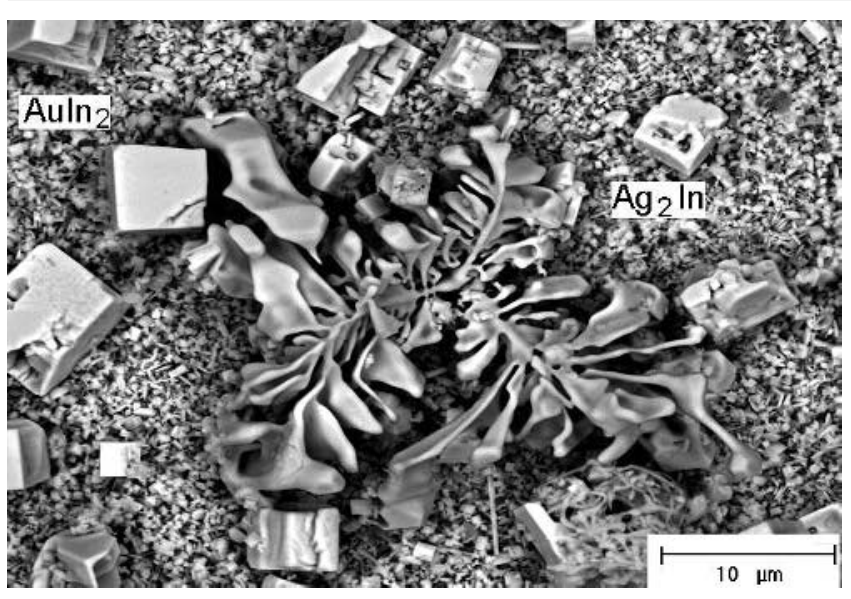

Fig. 3. Selective etching of the Sn-20In-2.8Ag solder showed that Auln ${ }_{2}$ intermetallic cubics and seaweed shaped $\mathrm{Ag}_{2} \mathrm{ln}$ on the $\mathrm{Ni} / \mathrm{Cu}$ pad in a BGA package after reflow at $230^{\circ} \mathrm{C}$ for 60 sec.

exhausted and a large amount of column-shaped intermetallic compounds are grown toward the solder matrix as shown in Fig. 7. The composition (at.\%) of these intermetallic columns is $\mathrm{Cu}: \mathrm{Ni}: \mathrm{Sn}: \mathrm{In}$ $=41.31: 14.83: 40.38: 3.48$, which corresponds to the $\left(\mathrm{Cu}_{0.74} \mathrm{Ni}_{0.26}\right)_{6}\left(\mathrm{Sn}_{0.92} \mathrm{In}_{0.08}\right)_{5}$ phase. The formation of such a $\left(\mathrm{Cu}_{0.74} \mathrm{Ni}_{0.26}\right)_{6}\left(\mathrm{Sn}_{0.92} \mathrm{In}_{0.08}\right)_{5}$ intermetallic compound is attributed to the rapid dissolution of

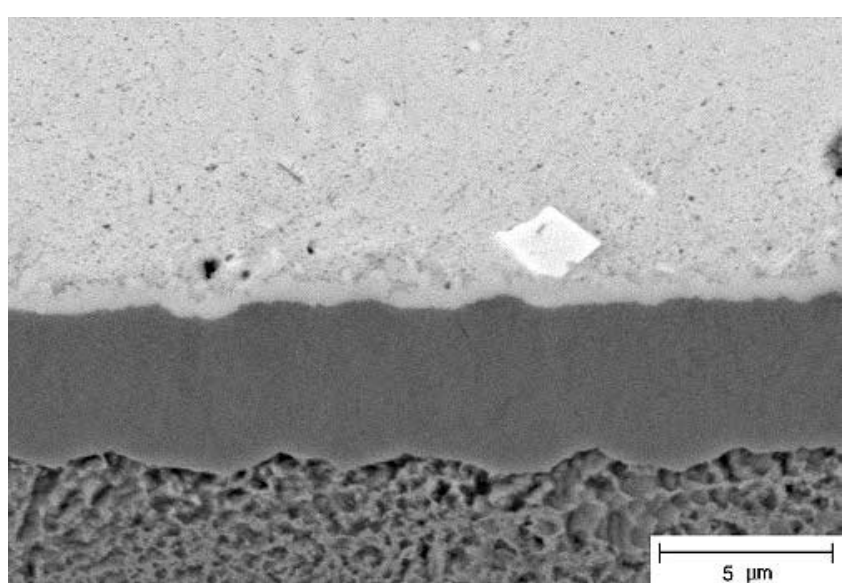

Fig. 4. Continuous $\mathrm{Ni}\left(\mathrm{Sn}_{0.72} \mathrm{In}_{0.27}\right)_{2}$ intermetallic layer formed during the reflowing of BGA Sn-20ln-2.8Ag solder at $230^{\circ} \mathrm{C}$ for $60 \mathrm{sec}$.

$\mathrm{Cu}$ atoms from the $\mathrm{Cu}$ pad through the loosened $\mathrm{Ni}\left(\mathrm{Sn}_{0.72} \mathrm{In}_{0.28}\right)_{2}$ intermetallic layer into the solder matrix. During the reaction between $\mathrm{Cu}$ atoms and Sn-20In-2.8Ag solder, the $\mathrm{Ni}\left(\mathrm{Sn}_{0.72} \mathrm{In}_{0.28}\right)_{2}$ intermetallic layer falls to pieces and joins in the $\mathrm{Cu} / \mathrm{Sn}-20 \mathrm{In}-2.8 \mathrm{Ag}$ reaction.

Ball shear strengths of the Sn-20In-2.8Ag solder joints in BGA packages after reflow at various peak temperatures for various melting times, are plotted 

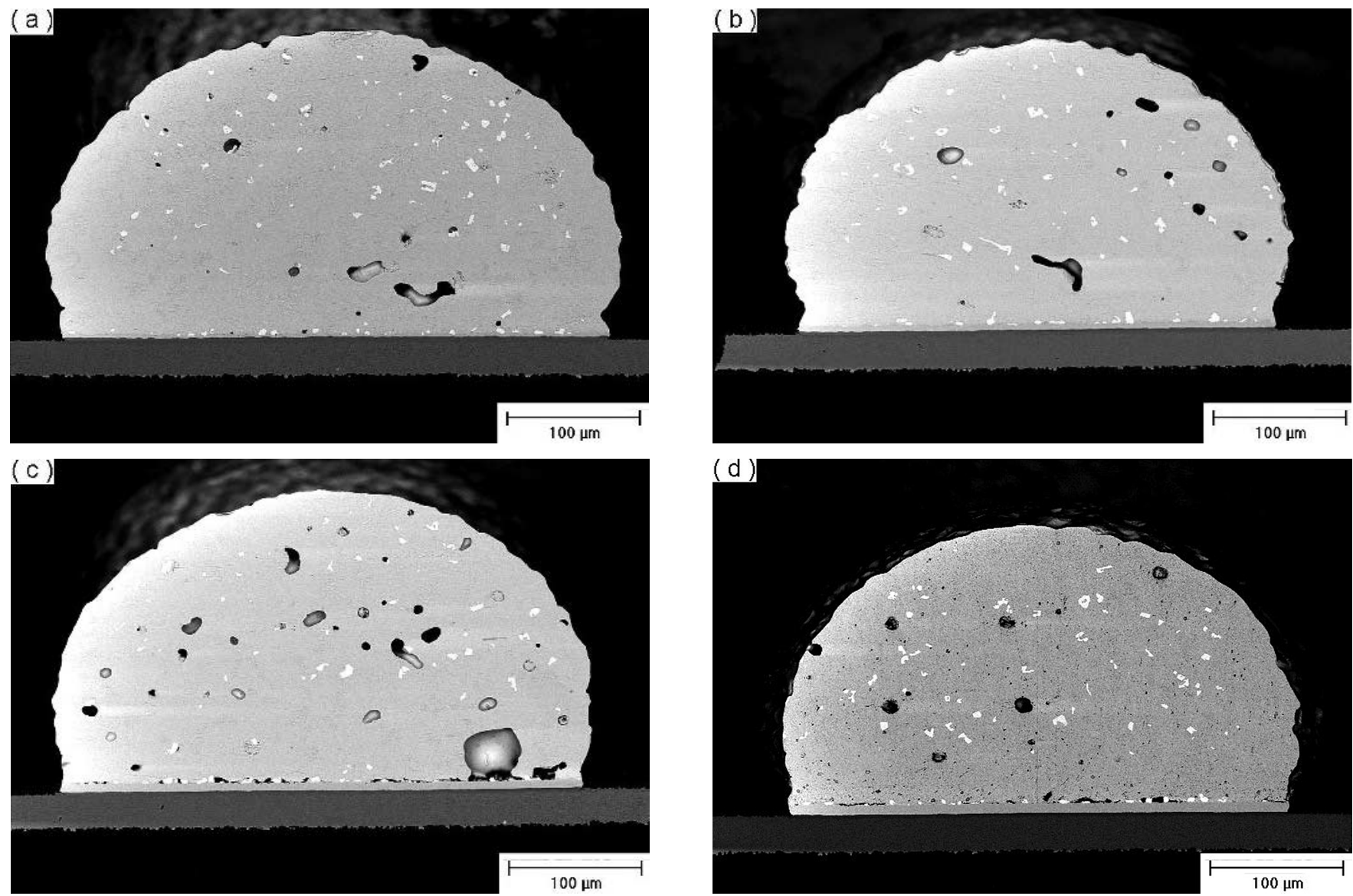

Fig. 5. Microstructure of the intermetallic compounds formed during the aging $\mathrm{Sn}-20 \mathrm{In}-2.8 \mathrm{Ag} \mathrm{BGA}$ packages with $\mathrm{Au} / \mathrm{Ni} / \mathrm{Cu}$ finishes at $100^{\circ} \mathrm{C}$ for various time periods: (a) $100 \mathrm{~h}$, (b) $500 \mathrm{~h}$, (c) $700 \mathrm{~h}$, and (d) $1000 \mathrm{~h}$.

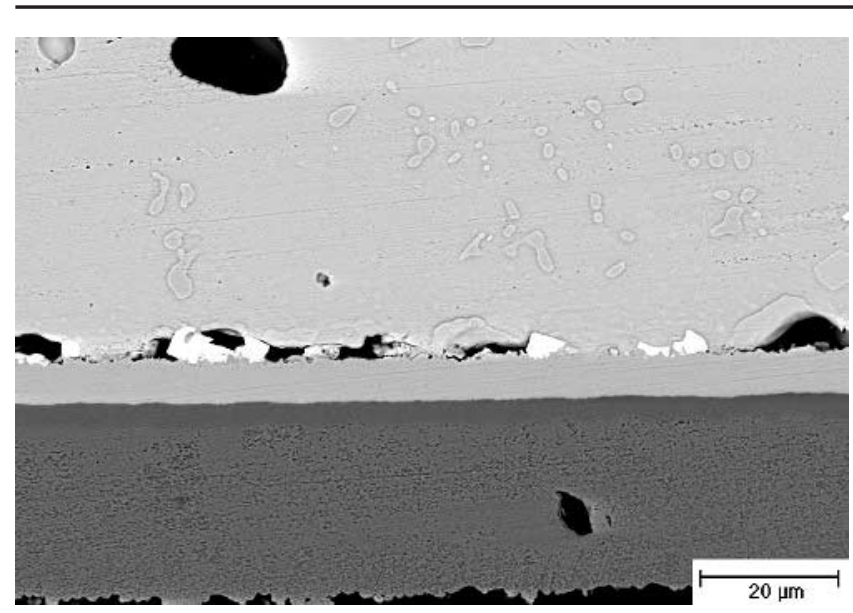

Fig. 6. Crack formed along the solder/pad interface after aging at $100^{\circ} \mathrm{C}$ for $700 \mathrm{~h}$.

in Fig. 8. An optimized condition for the reflow process can be obtained at $230^{\circ} \mathrm{C}$ for $60 \mathrm{sec}$, which results in the maximal bonding strength of $5.03 \mathrm{~N}$. This is higher than the ball shear strength of the reflowed In-49Sn package $(3.30 \mathrm{~N}),{ }^{14}$ but lower than that for the case of $\mathrm{Sn}-3.5 \mathrm{Ag}(8.69 \mathrm{~N}){ }^{18}$ After aging at $100^{\circ} \mathrm{C}$ and $150^{\circ} \mathrm{C}$ for $300 \mathrm{~h}$, the bonding strength of Sn-20In-2.8Ag solder joints drops slightly to $4.19 \mathrm{~N}$ and $4.79 \mathrm{~N}$, respectively, as shown in Fig. 9.

With further increases in aging time at $100^{\circ} \mathrm{C}$, the ball shear strengths decline progressively to the values around $3.50 \mathrm{~N}$. However, aging at $150^{\circ} \mathrm{C}$ for 500 $\mathrm{h}$ causes the strength to rise to $5.68 \mathrm{~N}$. Figures 10 shows the fractography done on the solder joints after ball shear tests in order to shed more light on the bonding strength results given in Fig. 9 for Sn20In-2.8Ag BGA packages after various aging treatments. It is evident that the specimens after reflow and aging for $300 \mathrm{~h}$ fracture across the solder matrix and reveal ductile characteristics (Fig. 10a). After aging at $100^{\circ} \mathrm{C}$ for $1000 \mathrm{~h}$, the outer region of the solder joint maintains the features of ductile fracture, as shown in Fig. 10b. However, the interior of the solder joint has fractured along the solder/pad interface, containing many $\mathrm{AuIn}_{2}$ intermetallic cubics and $\mathrm{Ni}\left(\mathrm{Sn}_{0.72} \mathrm{In}_{0.28}\right)_{2}$ intermetallic compounds. For a $\mathrm{Sn}$ 20In-2.8Ag package subjected to prolonged aging at $100^{\circ} \mathrm{C}$, such a fracture characteristic reveals that the continuously distributed voids along the solder/pad interface (Fig. 5d) should account for the low bonding strength of this specimen. The fractography in Fig. 10c indicates that the specimen after aging at $150^{\circ} \mathrm{C}$ for $500 \mathrm{~h}$ fractures across the $\left(\mathrm{Cu}_{0.74} \mathrm{Ni}_{0.26}\right)_{6}$ $\left(\mathrm{Sn}_{0.92} \mathrm{In}_{0.08}\right)_{5}$ intermetallic columns grown into the solder matrix. The microhardnesses of the $\left(\mathrm{Cu}_{0.74} \mathrm{Ni}_{0.26}\right)_{6}\left(\mathrm{Sn}_{0.92} \mathrm{In}_{0.08}\right)_{5}$ intermetallic compound and the Sn-20In-2.8Ag solder matrix have been 

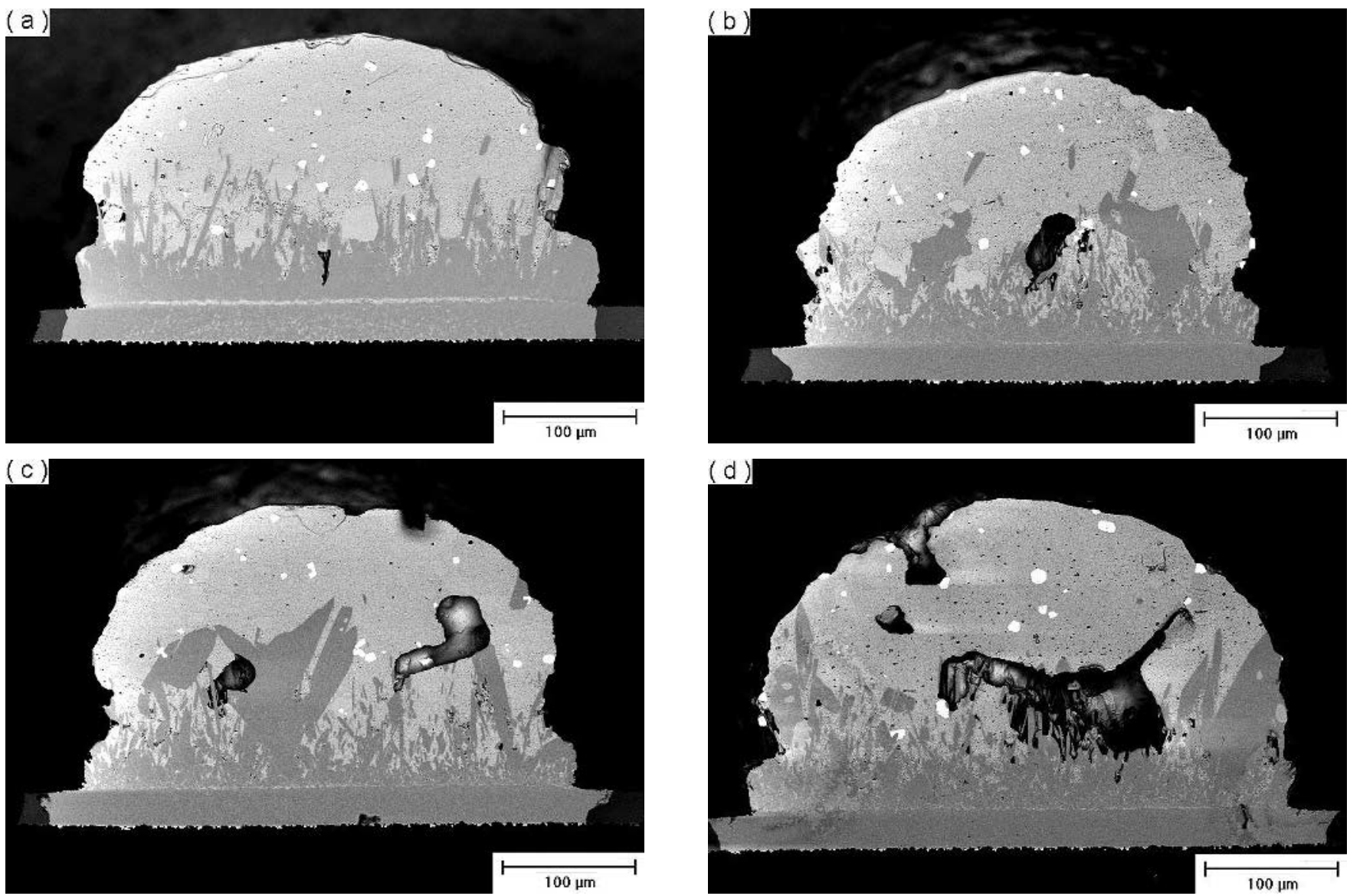

Fig. 7. Microstructure of the $\left(\mathrm{Cu}_{0.74} \mathrm{Ni}_{0.26}\right)_{6}\left(\mathrm{Sn}_{0.92} \mathrm{n}_{0.08}\right)_{5}$ intermetallic compounds formed during the aging Sn-20In-2.8Ag BGA packages with $\mathrm{Au} / \mathrm{Ni} / \mathrm{Cu}$ finishes at $150^{\circ} \mathrm{C}$ for various time periods: (a) $100 \mathrm{~h}$, (b) $500 \mathrm{~h}$, (c) $700 \mathrm{~h}$, and (d) $1000 \mathrm{~h}$.

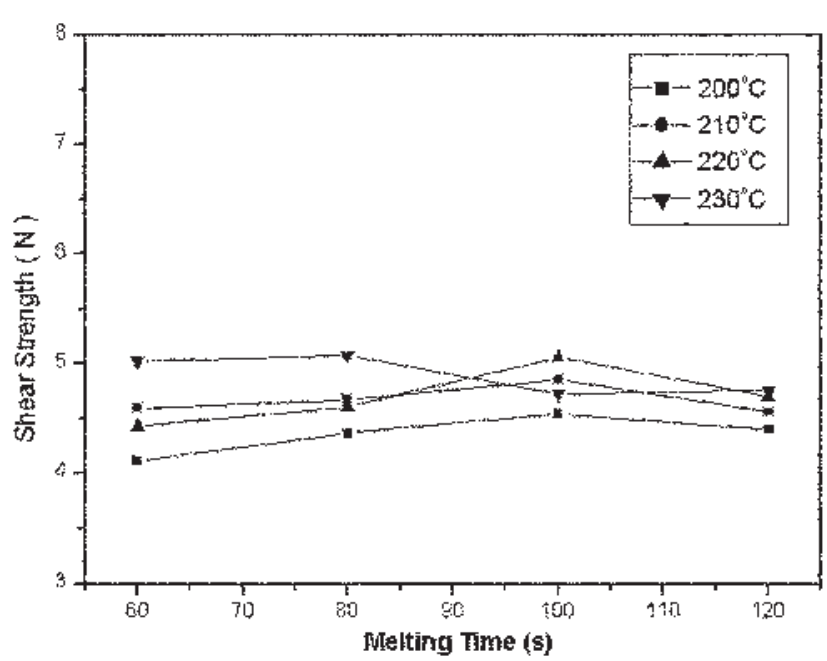

Fig. 8. Ball shear strengths of the solder joining in Sn-20ln-28Ag $\mathrm{BGA}$ packages with $\mathrm{Au} / \mathrm{Ni} / \mathrm{Cu}$ pads reflowed at various peak temperatures for various melting durations.

measured to be $300 \mathrm{HV}$ and $15 \mathrm{HV}$, respectively. The increase in ball shear strength of the solder joint after aging at $150^{\circ} \mathrm{C}$ for $500 \mathrm{~h}$ can thus be explained.

\section{CONCLUSIONS}

After the reflow operation of liquid Sn-20In-2.8Ag solder on $\mathrm{Au} / \mathrm{Ni} / \mathrm{Cu}$ pads in $\mathrm{BGA}$ packages, a

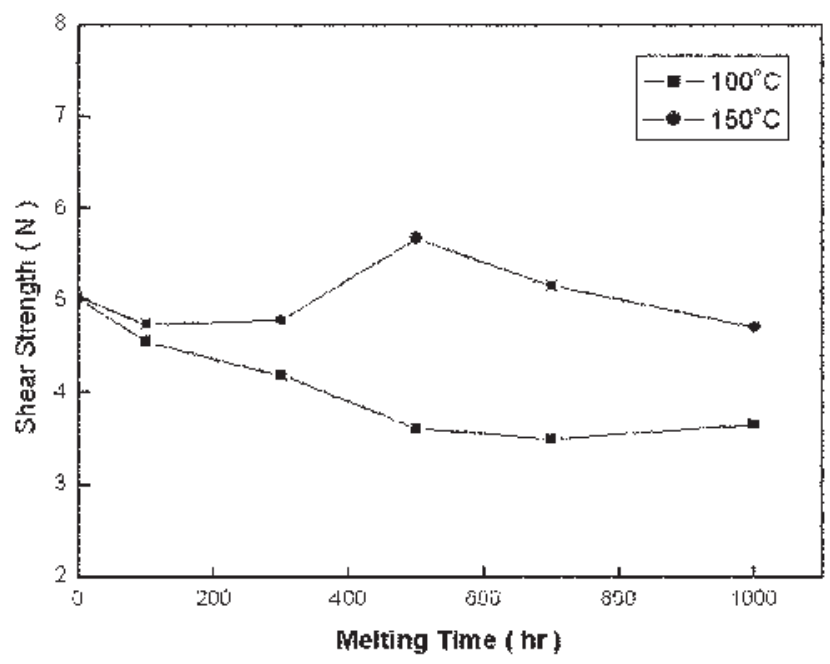

Fig. 9. Ball shear strengths of the Sn-20In-2.8Ag BGA packages with $\mathrm{Au} / \mathrm{Ni} / \mathrm{Cu}$ finishes after aging at $100^{\circ} \mathrm{C}$ and $150^{\circ} \mathrm{C}$ for various time periods.

number of cubic-shape $\mathrm{AuIn}_{2}$ intermetallic compounds appear in the solder along with $\mathrm{Ag}_{2} \mathrm{In}$ precipitates. A $\mathrm{Ni}\left(\mathrm{Sn}_{0.72} \mathrm{Ni}_{0.28}\right)_{2}$ continuous intermetallic layer is formed at the solder/pad interface, which exhibits no significant growth at $100^{\circ} \mathrm{C}$ with the increase in aging time. For the aging time longer than $700 \mathrm{~h}$, the continuously distributed voids, which 

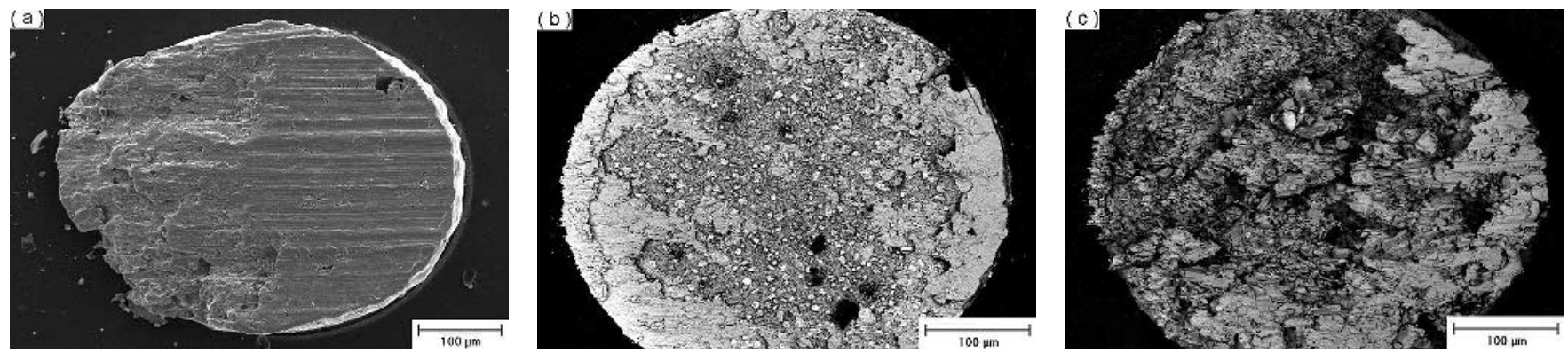

Fig. 10. Typical fractography of solder joints in Sn-20In-2.8Ag BGA packages after ball shear tests: (a) aging at $100^{\circ} \mathrm{C}$ for $300 \mathrm{~h}$, (b) aging at $100^{\circ} \mathrm{C}$ for $1000 \mathrm{~h}$, and (c) aging at $150^{\circ} \mathrm{C}$ for $500 \mathrm{~h}$.

have made their appearance along the solder/pad interface, cause the bonding strength to decrease form $5.03 \mathrm{~N}$ (as reflowed) to $3.50 \mathrm{~N}$. After prolonged aging at $150^{\circ} \mathrm{C}$, many column-shaped $\left(\mathrm{Cu}_{0.74} \mathrm{Ni}_{0.26}\right)_{6}$ $\left(\mathrm{Sn}_{0.92} \mathrm{In}_{0.08}\right)_{5}$ intermetallic compounds are formed at the solder/pad interface. The high microhardness $(300 \mathrm{HV})$ of these intermetallic columns is responsible for the increase in bonding strength of the Sn20In-2.8Ag BGA solder joints after aging at $150^{\circ} \mathrm{C}$ for $500 \mathrm{~h}$.

\section{ACKNOWLEDGEMENT}

The authors sincerely acknowledge the financial support from the National Science Council, Taiwan, for this research (Grant No. NSC.93-2216-E002-024).

\section{REFERENCES}

1. J. Glazer, Int. Mater. Rev. 40, 65 (1995).

2. W.K. Choi and H.M. Lee, J. Electron. Mater. 29, 1207 (2000).

3. S. Kang and A. Sarkhel, J. Electron. Mater. 23, 701(1994).
4. O. Hiroshi, M. Masamitsu, and I. Kiyohito, J. Jpn. Inst. Met. 63, 685 (1999).

5. U.R. Kattner and W.J. Boettinger, J. Electron. Mater. 23, 603 (1994).

6. Y. Kariya and M. Otsuka, J. Electron. Mater. 27, 1229 (1998).

7. J. Glazer, Int. Mater. Rev. 40, 65 (1995).

8. N.C. Lee, Soldering Surf. Mount Technol. 26, 25 (1997).

9. D.M. Jacobson and G. Humpston, Gold Bull. 22, 9 (1989).

10. P.G. Kim and K.N. Tu, Mater. Chem. Phys. 53, 165 (1998).

11. K.W. Huang and T.H. Chuang, J. Mater. Eng. Performance, in press (2005).

12. T. H. Chuang, K.W. Huang, and W.H. Lin, J. Electron. Mater. 33, 374 (2004).

13. M.J. Chiang and T.H. Chuang, Z. Metallkd. 93, 1194 (2002).

14. T.H. Chuang, S.Y. Chang, L.C. Tsao, W.P. Weng, and H.M. Wu, J. Electron. Mater. 32, 195 (2003).

15. Y. H. Tseng (Ph.D. Thesis, National Taiwan University, 2000).

16. T.H. Chuang, K.H. Huang, and W.H. Lin, J. Electron. Mater. 33, 4 (2004).

17. C.Y. Huang and S.W. Chen, J. Electron. Mater. 31, 2 (2002).

18. T.L. Yu (Ph. D. Thesis, National Taiwan University, 2003). 